\title{
Huntington's disease mouse models: unraveling the pathology caused by CAG repeat expansion
}

\author{
Julia Kaye $^{1}$ Terry Reisine ${ }^{2}$ Steve Finkbeiner ${ }^{1,3,4^{*}}$ \\ ${ }^{1}$ Center for Systems and Therapeutics, Gladstone Institutes, San Francisco, CA, USA \\ ${ }^{2}$ Independent Scientific Consultant, Santa Cruz, CA, USA \\ ${ }^{3}$ Taube/Koret Center for Neurodegenerative Disease Research, Gladstone Institutes, San Francisco, CA, USA \\ ${ }^{4}$ Department of Neurology and Physiology, University of California, San Francisco, CA, USA
}

\begin{abstract}
Huntington's disease (HD) is a neurodegenerative disease that results in motor and cognitive dysfunction, leading to early death. HD is caused by an expansion of CAG repeats in the huntingtin gene (HTT). Here, we review the mouse models of HD. They have been used extensively to better understand the molecular and cellular basis of disease pathogenesis as well as to provide non-human subjects to test the efficacy of potential therapeutics. The first and best-studied in vivo rodent model of HD is the R6/2 mouse, in which a transgene containing the promoter and exon 1 fragment of human $H T T$ with 150 CAG repeats was inserted into the mouse genome. R6/2 mice express rapid, robust behavioral pathologies and display a number of degenerative abnormalities in neuronal populations most vulnerable in HD. The first conditional full-length mutant huntingtin (mHTT) mouse model of HD was the bacterial artificial chromosome (BAC) transgenic mouse model of HD (BACHD), which expresses human full-length $\mathrm{m} H T T$ with a mixture of $97 \mathrm{CAG}-\mathrm{CAA}$ repeats under the control of endogenous HTT regulatory machinery. It has been useful in identifying the role of mHTT in specific neuronal populations in degenerative processes. In the knock-in (KI) model of HD, the expanded human CAG repeats and human exon 1 are inserted into the mouse Htt locus, so a chimera of the full-length mouse protein with the N-terminal human portion is expressed. Many of aspects of the pathology and behavioral deficits in the KI model better mimic disease characteristics found in HD patients than other models. Accordingly, some have proposed that these mice may be preferable models of the disease over others. Indeed, as our understanding of HD advances, so will the design of animal models to test and develop HD therapies.
\end{abstract}

\section{Keywords}

R6/2 mouse model, BACHD, Huntington's disease, mouse models, neurodegeneration, neurodegenerative disease

\section{Peer Review}

The peer reviewers who approve this article are:

1. Scott Zeitlin, Department of Neuroscience, University of Virginia School of Medicine, Charlottesville, VA, USA Competing interests: No competing interests were disclosed.

2. Irina Dudanova, Molecular Neurodegeneration Group, Max Planck Institute of Neurobiology, Martinsried, Germany Competing interests: No competing interests were disclosed. 
*Corresponding author: Steve Finkbeiner (sfinkbeiner@gladstone.ucsf.edu)

Competing interests: The authors declare that they have no competing interests.

Grant information: The funding that supported this work was from National Institutes of Health grant 1 R01 NS101996-01.

The funders had no role in study design, data collection and analysis, decision to publish, or preparation of the manuscript.

Copyright: $\odot 2021$ Finkbeiner S et al. This is an open access article distributed under the terms of the Creative Commons Attribution License, which permits unrestricted use, distribution, and reproduction in any medium, provided the original work is properly cited.

How to cite this article: Kaye J, Reisine T and Finkbeiner S. Huntington's disease mouse models: unraveling the pathology caused by CAG

repeat expansion. Faculty Reviews 2021 10:(77) https://doi.org/10.12703/r/10-77

Published: 21 Oct 2021, Faculty Reviews 10:(77) https://doi.org/10.12703/r/10-77 


\section{Introduction}

Huntington's disease (HD) is caused by an expansion of CAG repeats in the huntingtin gene $(H T T)^{1}$, which leads to neurological deficits, including motor impairment ${ }^{2}$ and cognitive decline $^{3}$. Normal $H T T$ alleles contain fewer than 35 CAG repeats, a CAG repeat of 40 or more is considered a fully penetrant mutation, whereas tracts of 36 to 39 CAGs impart an increased risk of developing the disease ${ }^{4-6}$. There is a well-established correlation between the number of CAG repeats and age of onset $^{7,8}$. With extreme CAG expansion, symptoms develop in childhood, pathology is extensive, and life is short. However, CAG repeat length does not fully explain the severity of HD: $30 \%$ to $50 \%$ of the variation in age of onset is not related to CAG repeat length ${ }^{9}$. Polymorphisms in genes other than HTT contribute to age of onset in $\mathrm{HD}^{9-12}$. For example, polymorphisms in the FANC1-associated nuclease 1 (FANI) gene, which encodes a DNA repair enzyme, affect age of onset of $\mathrm{HD}^{11-13}$.

In addition to motor and cognitive decline, neuropsychiatric symptoms, including depression and anxiety ${ }^{14}$, are present in patients with HD and are thought to typically predate the onset of motor symptoms ${ }^{15}$. Other common systemic features of HD include weight loss due to changes in metabolism ${ }^{16}$ and sleep and circadian rhythm disturbances ${ }^{17}$. Symptoms usually begin in midlife, and death follows within 10 to 20 years ${ }^{18-20}$.

A prominent neuropathological feature of HD is neurodegeneration, including neuronal death in the striatum, which is a major relay center of cortical signaling through the basal ganglia and is critically involved in regulating motor function and cognition ${ }^{21,22}$. As a consequence, impaired striatal physiology, including changes at glutamatergic, dopaminergic (DA), and cholinergic synapses, may be evident during the pre-symptomatic phase of $\mathrm{HD}^{23-31}$.

Within the striatum, the most prominent neuropathology in $\mathrm{HD}$ is the loss of medium spiny-like neurons (MSNs), also known as spiny projection neurons (SPNs), and their cortical pyramidal neuronal innervation ${ }^{2,32}$. MSNs are the earliest affected neuronal population in HD (Figure 1) and undergo significant loss of dendritic structure and spines with disease progression in humans and animal models ${ }^{33-39}$. The cortico-striatal neurons are also affected in $\mathrm{HD}^{40}$ and impact cognitive decline ${ }^{41}$. The polyglutamine stretch in mutant huntingtin (mHTT) causes hyperactivity of glutamatergic cortico-striatal neurons and enhanced striatal glutamatergic transmission, which begins during the asymptomatic phase of $\mathrm{HD}^{27-29,42}$ and contributes to synaptic changes observed in later stages (Figure 1). Dysregulated glutamate release at cortico-striatal synapses results in aberrant calcium signaling leading to excitotoxity and is believed to be one of the causes of MSN vulnerability in $\mathrm{HD}^{24,28,29}$. Genetically reducing mHTT expression selectively in cortico-striatal neurons rescues electrophysiological alterations in striatal MSNs and reduces motor disabilities in mice ${ }^{43}$. Thus, early in the disease, a hyperactivity of glutamatergic cortico-striatal neurons driven by mHTT expression causes MSN dysfunction, which may influence the gradual death of striatal neurons over time. Brain imaging studies in pre-symptomatic HD carriers have shown that cortical atrophy occurs early, develops progressively, and correlates with the expression and severity of cognitive and motor symptoms ${ }^{44-46}$. The loss of cortico-striatal neurons leads to hypoglutamatergic input to the striatum at later stages of the disease. This suggests that the circuitry within the cortico-striatal glutamate neurons and MSNs plays a critical role in striatal dysfunction, MSN death, and HD pathogenesis ${ }^{47}$.

MSNs give rise to two distinct pathways that project to either the substantia nigra pars reticulata $(\mathrm{SNr})$ and internal segment of the globus pallidus (GPi) (the direct pathway) or the external segment of the globus pallidus (GPe), which in turn projects to the subthalamic nucleus $(\mathrm{STN})^{48,49}$ (the indirect pathway). MSNs projecting to the GPe appear to be affected earlier in HD than the other projection pathway and this has been proposed to cause an imbalance in the two pathways and the emergence of involuntary movements and chorea ${ }^{50,51}$. Whereas MSNs are vulnerable in HD, other striatal neuronal types such as GABA interneurons, including those expressing somatostatin and calretinin, are preserved in the disease ${ }^{52}$. It has been suggested that MSN degeneration may be linked to a loss of neurotrophic support ${ }^{53,54}$ and altered glutamate released from cortico-striatal neurons.

In addition to glutamatergic control, the different MSN projecting neurons are regulated by DA nigrostriatal neurons via activation of either D1 DA receptors or D2 DA receptors. The different populations of striatal MSNs differentially express the receptors; MSNs projecting to the $\mathrm{SNr}$ express D1 DA receptors, while MSNs projecting to the GPe primarily express D2 DA receptors ${ }^{55,56}$. Dopamine released from nigrostriatal neurons diminishes cortico-striatal glutamatergic excitation of the D2-expressing MSN striatopallidal neurons and may be neuroprotective ${ }^{57-59}$. In contrast, striatal stimulation of D1 DA receptors in MSNs appears to enhance glutamatergic transmission and may contribute to neurodegeneration and neuronal loss in the striatum and MSN-SNr projecting neurons ${ }^{60-62}$.

Whereas these studies suggest opposing roles of D1 and D2 DA receptors with regard to glutamate toxicity in the striatum, other work has shown that antagonism of both receptors reduces neuronal loss in the striatum ${ }^{58}$ and that blocking D2 receptor stimulation significantly reverses DA potentiation of mHTT-induced MSN cell death ${ }^{63}$. Consistent with the loss of MSNs in HD, both D1 and D2 DA receptor densities in the striatum are decreased in $\mathrm{HD}$, even in asymptomatic patients, indicating that DA signaling is disrupted in the disease ${ }^{64-66}$. Striatal D1 and D2 DA receptor densities are also reduced in different animal models of $\mathrm{HD}^{67-70}$. Loss of DA receptors in patients with early-stage HD has been correlated with early cognitive decline ${ }^{71}$.

Genetic models have been developed to study both the molecular and cellular basis of HD and to provide systems to identify novel therapeutics, including small-molecule drugs, 

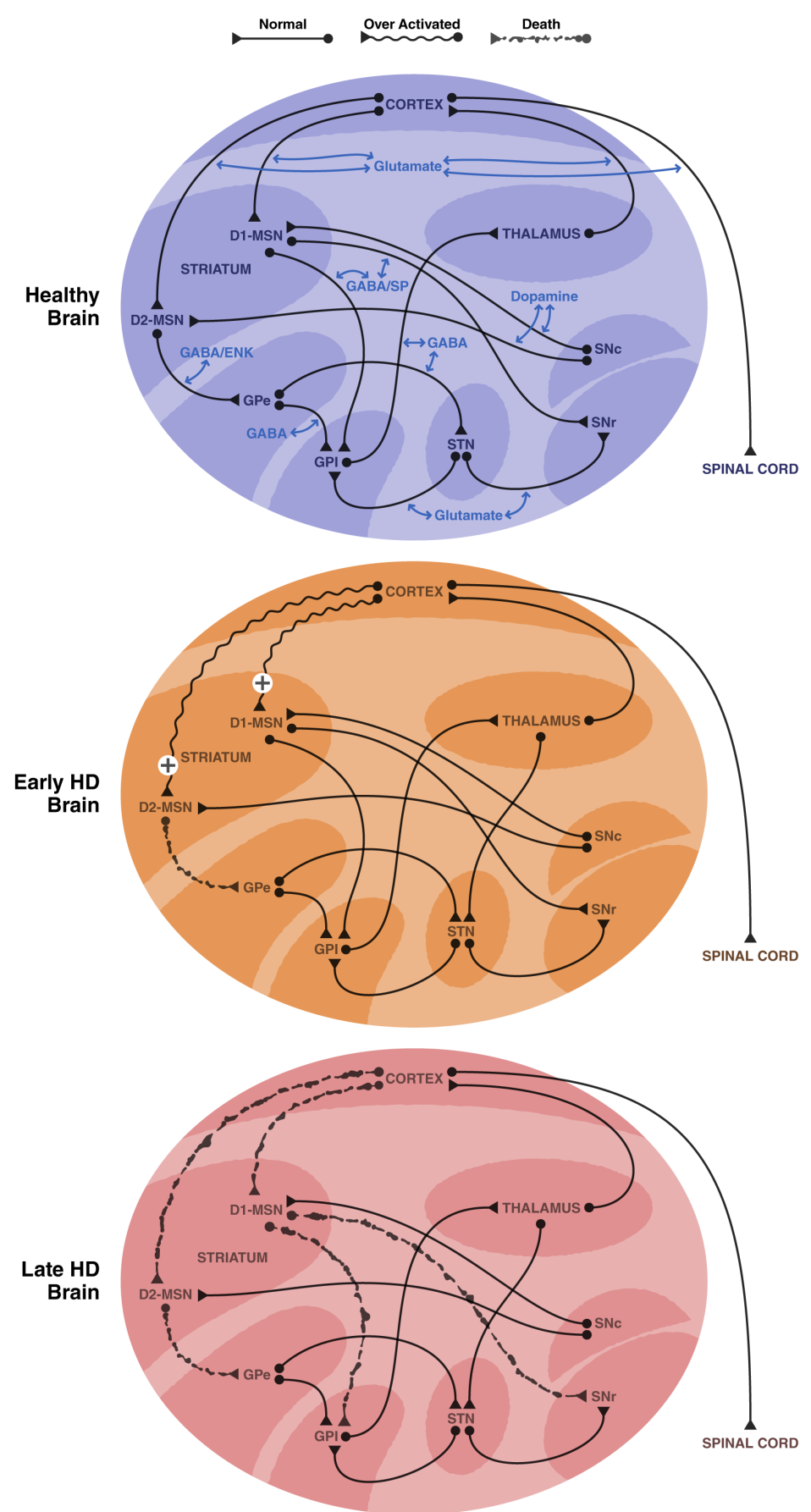

Figure 1. Alterations in Neuronal Circuitry in the Basal Ganglia in HD. A) Normal basal ganglia: The direct pathway consists of striatal medium spiny-like neurons (MSNs) expressing D1 dopamine receptors (D1-MSN) that project GABA/substance P (SP) neurons to the internal capsule of the internal globus pallidus (GPi) and the substantia nigra reticulata (SNr). The indirect pathway consists of MSNs expressing D2 dopamine receptors (D2-MSN) that project GABA/Enkephalin (Enk) neurons to the external capsule of the external globus pallidus (GPe) which then projects GABA neurons to the subthalamic nucelus (STN). The STN projects glutamate neurons to the GPi and SNr. The MSNs are innervated by dopamine neurons from the substantia nigra compacta (SNc) and by glutamate neurons from the cortex. The GPi projects inhibitory GABA neurons to the thalamus, and the thalamus projects excitatory glutamate neurons to the cortex. The motor cortex also projects glutamate neurons to the spinal cord to control movement. B) Basal ganglia at early stages of Huntington's disease (HD): Cortical glutamate neuronal input to the striatum is hyperactive at early stages of HD, based on animal model work (R6/2 mice). This causes excitotoxicity. D2-MSNs are believed to be more sensitive to the glutamate hyperactivity and begin to degenerate first. The diminished GABA/Enk input to the GPe can produce an imbalance in the basal ganglia function and increase activity in the GPe which subsequently alters activity in the STN. C) Basal ganglia at later stages of HD: Both the cortex and striatum show degeneration in later stages of HD. The lost cortical glutamate neurons result in hypoactivity in the striatum. Both the D1-MSNs and the D2-MSNs degenerate. 
biologicals, nucleic acids, and cell-based therapeutics to slow progression of the disease. Here, we will focus on the development and use of transgenic mouse models to study HD. We emphasize electrophysical results that have begun to elucidate mechanisms of neuronal circuit dysfunction that may be related to behavioral deficits in HD.

\section{In vivo HTT transgenic mouse models}

\section{R6/2 mouse model of Huntington's disease}

The first in vivo rodent model of $\mathrm{HD}$ to be developed was the R6 line, including the R6/1 and R6/2 models ${ }^{72}$. (See Table 1 for summary of results of mouse models.) The R6/2 mouse model, which is the most widely studied, has a transgene containing the promoter and exon 1 fragment of human HTT with $150 \mathrm{CAG}$ repeats inserted into the mouse genome ${ }^{73}$. The R6/2 model robustly demonstrates the pathological hallmarks of $\mathrm{HD}$, such as motor dysfunction and inclusion body (IB) formation and premature death ${ }^{73-76}$. The mice survive for about 15 weeks, and mHTT aggregates and inclusions form before the emergence of behavioral phenotypes, which include irregular gait, clasping, weight loss, increased grooming, and cognitive deficits by 5 weeks of age $^{73}$. As the mice age, they develop seizures. Because of the rapid progression of disease phenotypes, the $\mathrm{R} 6 / 2$ mice have been proposed as a model of juvenile HD.

R6/2 mice display a number of degenerative abnormalities in electrophysiological properties of MSNs and cortico-striatal neurons that may contribute to the rapid appearance and progression of motor and cognitive deficits. The MSNs of symptomatic R6/2 mice have reduced membrane capacitance and increased input resistance, caused by reduced $\mathrm{K}^{+}$channel expression $^{24,34,77}$. Spontaneous GABA currents and inhibitory post-synaptic currents are increased in R6/2 $\mathrm{MSNs}^{78,79}$, whereas excitatory post-synaptic currents (EPSCs) are decreased $^{24,80-82}$, which together result in a decrease in burst firing in the striatum.

The electrophysiological properties of the two populations of striatal MSNs - those innervating the $\mathrm{SNr}$ and those innervating $\mathrm{GPe}$ - are differentially affected in $\mathrm{R} 6 / 2$ mice, resulting in an imbalance in striatal output that may contribute to motor dysfunction $^{83}$. GABAergic MSNs that innervate the $\mathrm{SNr}$ have reduced activity in $\mathrm{R} 6 / 2$ mice, resulting in reduced $\mathrm{GABA}_{\mathrm{A}}$ receptor-mediated responses in the $\mathrm{SNr}$ and hyperactivity of DA neurons. This hyperactivity may contribute to HD progression $^{57}$. In contrast to the MSNs projecting to the $\mathrm{SNr}$, GABAergic MSNs projecting to the GPe showed increased responses in the GPe. In addition, early on, the cortical pyramidal glutamatergic neurons that project to MSNs become hyperexcitable in R6/2 mice and this enhanced activity precedes behavioral symptoms ${ }^{84}$. This was shown in a study by Burgold et al. (2019) ${ }^{85}$, who used chronic in vivo two-photon calcium imaging to study neurons in the motor cortex of behaving R6/2 mice. The R6/2 mice showed hyperactivity of the cortical neurons prior to the appearance of motor deficits. Furthermore, Fernández-García et al. $(2020)^{86}$ used optogenetic techniques to show that stimulation of degenerating secondary motor cortex neurons of R6/1 mice that project to the dorsolateral striatum reversed motor deficits and changes in long-term depression and normalized spine density within the striatum. The cortical neurons in the R6/2 mice exhibit decreased synchrony ${ }^{87}$, and synchrony between the cortex, striatum, and STN is disrupted ${ }^{88,89}$. In addition, glutamate uptake may be impaired ${ }^{47}$. Lack of uptake can lead to an overabundance of synaptic glutamate, which in turn can initiate an excitotoxic neuronal death cascade.

Relatedly, decreased expression of the glutamate transporter 1 (GLT-1) has been reported in the striatum and cortex of postmortem HD brains and R6/2 mice ${ }^{90-96}$. Studies in R6/2 mice showed that cortical pyramidal neurons are more sensitive to compromised glutamate reuptake and that failure in this system might lead to overactivation of glutamate receptors in the frontal cortex and striatum ${ }^{91}$. Interestingly, as frontal cortical pyramidal neurons in the R6/2 mice are more prone to paroxysmal activity, this brain area might be a trigger for the development of epileptic seizures observed in R6/2 mice ${ }^{84,97}$. GLT-1 is predominantly expressed in astrocytes ${ }^{98}$, suggesting a critical role of astrocytes in neurodegeneration, revealing that the pathology caused by mHTT is not limited to neurons ${ }^{99,100}$. The rapid progression of phenotypes in $\mathrm{R} 6 / 2$ mice is particularly useful in trying to identify potential disease-modifying agents. Indeed, recent studies using R6/2 mice have revealed a promising cell-based therapy to treat HD using human embryonic stem cell-derived neuronal stem cells $(\mathrm{hNSCs})^{101}$.

Although the R6/2 model exhibits robust disease-related phenotypes, there are caveats. Primarily, the transgene contains only the first exon of $H T T$; therefore, the protein lacks motifs such as the HEAT domain, through which HTT interacts with other proteins ${ }^{102,103}$. In addition, this fragment lacks post-translational modification sites that control HTT cleavage and may contribute to toxicity of $\mathrm{mHTT}^{104-106}$. These limitations may explain why the pathological consequences of R6/2 mice differ from those of other transgenic mouse models of $\mathrm{HD}$, described in more detail below.

\section{N171-82Q mouse model of Huntington's disease}

Another HD model that expresses an N-terminal fragment of human mHTT is the N171-82Q mouse. The mouse carries a cDNA encoding the N-terminus of human HTT with the initial 171 amino acids and 82 CAG repeats, driven by the mouse prion promoter $^{107}$. N171-82Q mice show striatal atrophy and modest MSN degeneration, ventricular enlargement, and a failure to gain weight ${ }^{108,109}$. They develop tremors, hypokinesia, and lack of coordination. The N171-82Q mice have a more delayed disease onset and longer survival than R6/2 mice ${ }^{107}$.

N171-82Q mice also exhibit altered functional neuronal connectivity, as assessed by functional magnetic resonance imaging $(\mathrm{fMRI})^{110}$. Bilateral connectivity between the motor cortices and somatosensory cortices is reduced in these mice, as is intrastriatal connectivity. The weak intrastriatal connectivity is positively correlated with striatal atrophy and reduced motor 


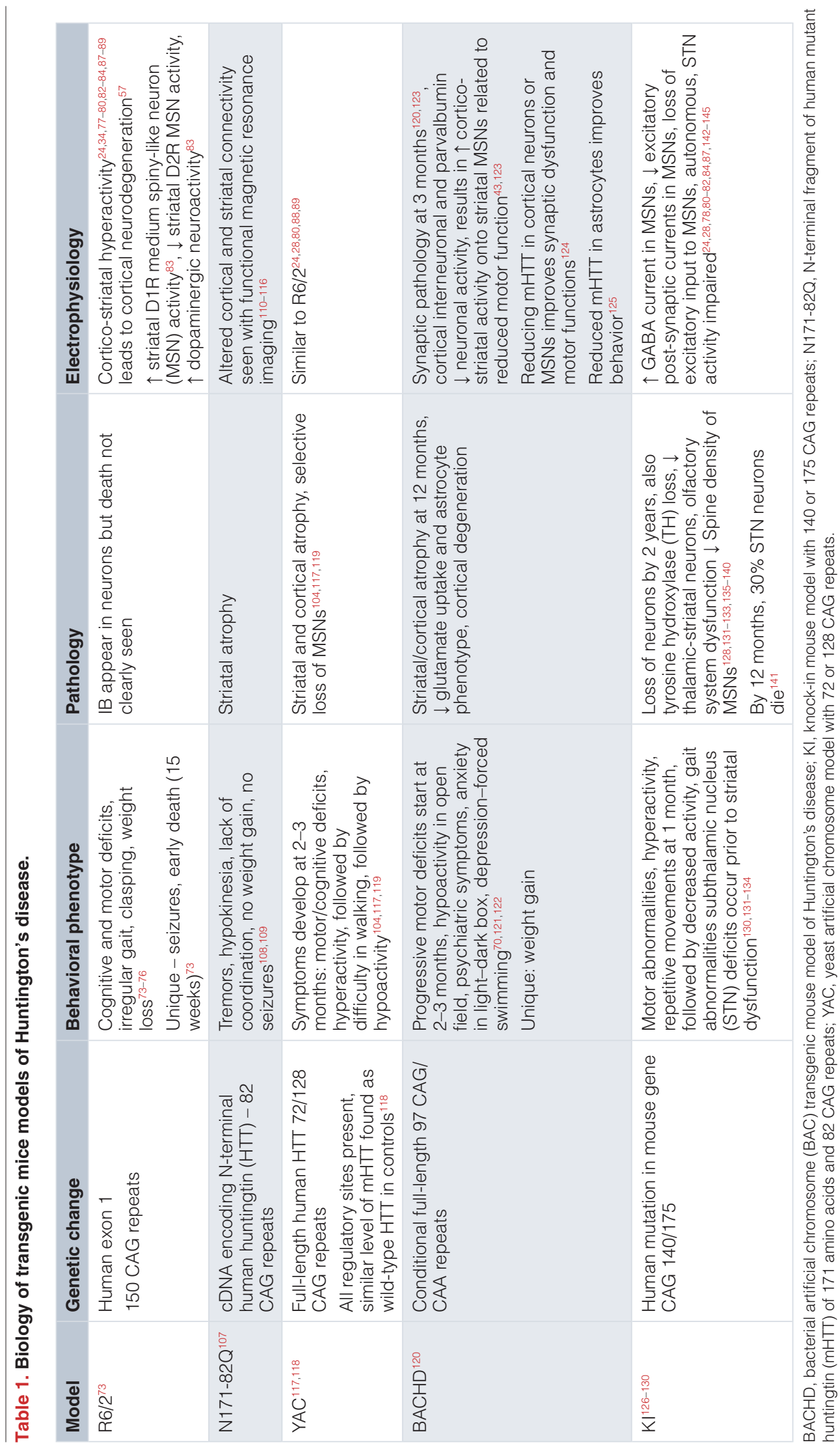


function. In these respects, the mice mirror patients with HD, as fMRI also shows altered functional connectivity of cortical and thalamic regions associated with impaired motor function in patients with $\mathrm{HD}^{111-116}$. Reduced intrinsic functional connectivity is present even in premanifest HD gene carriers and to a much larger extent in patients with manifest $\mathrm{HD}^{111-116}$. These studies suggest that mHTT causes disruption of normal neuronal and functional linkage of brain regions involved in motor control and cognition.

YAC72 and YAC128 mouse models of Huntington's disease The first full-length human mHTT transgenic animal models harbored HTT with either 72 or 128 CAG repeats in a yeast artificial chromosome (YAC) that includes all of the human regulatory elements, such as the introns, integrated into the mouse $\mathrm{1}^{117,118}$. These models displayed a less severe phenotype than the R6/2 mice and express mHTT at levels similar to endogenous $\mathrm{HTT}^{118}$. At about 2 or 3 months of age, the mice develop symptoms, including motor and cognitive deficits that correlate with the appearance of mHTT aggregates and striatal and cortical atrophy ${ }^{104,117,119}$. The progression of symptoms begins with hyperactivity, followed by difficulty in walking along a rotating rod, and then hypokinesia. Deficits in rotarod performance correlate with loss of striatal neurons ${ }^{117}$. Many of the electrophysiological abnormalities of the MSNs and cortico-striatal neurons observed in R6/2 mice are similarly

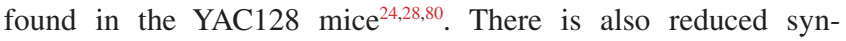
chrony between the cortex, striatum, and STN in the YAC128 mouse $^{88,89}$. This is consistent with findings in HD brain showing a progressive disconnect between the cortex and striatum with progression of striatal degeneration ${ }^{39,146}$.

In 2015, Pancani et al. reported that a muscarinic M4 receptor drug reduced the excessive cortical glutamatergic transmission in cortico-striatal slices of YAC128 mice $^{147}$. The normalization of glutamate transmission occurred via M4 receptors localized pre-synaptically to the cortical neuronal input. The drug also reduced motor deficits in the mice, suggesting that therapeutics designed to normalize the cortical striatal imbalance might be therapeutically useful.

Furthermore, Al-Gharaibeh et al. used the YAC128 model to demonstrate that induced pluripotent stem cell (iPSC)-derived NSCs have the potential as a treatment of $\mathrm{HD}^{148}$. Mouse iPSC-NSCs bilaterally implanted into the striatum of YAC128 mice differentiated into MSNs and reduced motor deficits. The protective effect of the cells was suggested to be related to their ability to increase levels of brain-derived neurotrophic factor, which supports the survival of remaining neurons in the striatum ${ }^{149-151}$.

\section{BACHD mouse model of Huntington's disease}

The first conditional full-length mHTT mouse model of HD was the bacterial artificial chromosome (BAC) transgenic mouse model of HD (BACHD), which expresses human full-length $\mathrm{m} H T T$ with a mixture of $97 \mathrm{CAG}$ and CAA repeats under the control of endogenous HTT regulatory machinery ${ }^{120}$. In terms of phenotype, the BACHD model is similar to the YAC128
HD mouse in many ways; progressive motor deficits are apparent as early as 2 months of age, and striatal and cortical atrophy occur at 12 months ${ }^{70}$. BACHD mice display hypoactivity in the open-field test ${ }^{121}$ as well as changes in affective behavioral phenotypes such as increased anxiety and depressive behavior at 6 months ${ }^{122}$.

Many of these phenotypes parallel the development of electrophysiological deficits in cortical pyramidal neurons, cortical interneurons, and striatal MSNs. This progressive synaptic pathology occurs around 3 months of age, when the motor deficits are still mild ${ }^{123}$. Electrophysiological analysis of MSNs of 6-month-old BACHD mice demonstrated selective reduction of large-amplitude EPSCs in striatal neurons ${ }^{120}$. These changes are paralleled by decreased cortical parvalbumin (PV) interneuron excitation and decreased pyramidal cell inhibition, resulting in increased cortico-striatal excitability onto striatal MSNs and a decline in motor function ${ }^{123}$.

Because synaptic dysfunction in cortico-striatal neurons and striatal MSNs is a critical neurodegenerative process in HD, researchers have used the BACHD mouse to study the effect of mHTT deletion in cortical pyramidal neurons, striatal MSNs, or both ${ }^{43}$. BACHD mice show significant reductions in $N$-methyl-D-aspartate (NMDA)-evoked synaptic responses in striatal MSNs in slices, and genetically reducing mHTT levels in either cortical pyramidal neurons or MSNs partially reversed this deficit. Furthermore, the MSNs of BACHD mice show reduced activity, indicated by reduced spontaneous EPSCs and increased spontaneous inhibitory post-synaptic currents (IPSCs), and these deficits are ameliorated by reducing mHTT levels in cortical pyramidal neurons. The synaptic deficits were more effectively improved when mHTT was removed from both MSNs and cortical pyramidal neurons. In addition, reducing mHTT levels in cortical neurons also improved neuronal activity in cortical neurons ${ }^{124}$. These findings suggest that mHTT in both cortico-striatal pyramidal neurons and MSNs contributes to synaptic deficits in striatal MSNs.

Removal of mHTT from cortical pyramidal neurons or MSNs partially reversed motor behaviors measured in the rotarod and locomotion tests, but removal of mHTT from both neuronal populations was required to restore these motor behaviors to wild-type control levels ${ }^{43}$. BACHD mice also exhibit anxiety-like behaviors as measured by light-dark box exploration and depression-like behavior in a forced swimming test. Reducing mHTT in cortico-striatal pyramidal neurons or both cortico-striatal pyramidal neurons and MSNs significantly improved these psychiatric behavioral deficits, whereas mHTT reduction in MSNs alone did not.

These studies suggest that mHTT in striatal MSNs contributes to some aspects of striatal pathogenesis, but the pathogenesis of many behavioral and neurodegenerative phenotypes likely requires mHTT expression in other populations. In particular, dysfunction of cortical pyramidal neurons due to expression of mHTT contributes to synaptic deficits in MSNs and motor and psychiatric behavioral deficits. These findings 
indicate distinct but interacting roles of cortical and striatal mHTT in HD pathogenesis and support a role for non-cell-autonomous mHTT toxicity in striatal pathogenesis.

There is also significant evidence that non-neuronal populations contribute to $\mathrm{HD}^{152}$. The BACHD model was recently used to investigate the role of mHTT in astrocytes on disease phenotypes ${ }^{125}$. That study showed that selective reduction of mHTT in astrocytes in the cortex and striatum improved striatal MSN synaptic responses and behavioral phenotypes. mHTT in astrocytes may contribute to neuronal dysfunction by altering the regulation of extracellular glutamate and other key aspects of synaptic transmission. Altered glutamate release in HD models has been described both in vitro and in vivo ${ }^{110,153}$, and impaired glutamate signaling might further occur in HD as a consequence of decreased glutamate uptake. Studies of HD postmortem brain and HD transgenic models have consistently shown decreased GLT-1, which is responsible for the bulk of glutamate uptake in astrocytes ${ }^{93-95}$. These findings support the role of astrocytes in mHTT-induced HD pathophysiology.

BACHD mice have also been used to study the role of posttranslational modifications of $\mathrm{mHTT}$, in particular protein phosphorylation, in disease pathogenesis. Three potential phosphorylation sites-serines 13 and 16 in the N-terminal region and serine 421 in the Akt consensus sequence-were studied $^{154,155}$. Biochemical studies have shown that phosphorylation at serines 13 and 16 significantly alters the structure of $\mathrm{mHTT}^{155}$, and phosphorylation at serine 421 alters the transport of mHTT $^{156}$, suggesting that post-translational modifications at these sites may affect function of this protein. For the studies in BACHD mice, mHTT constructs were generated in which the serines were converted to aspartates to mimic phosphorylation or to alanine to prevent phosphorylation. The phosphomimetic substitutions were protective and rescued locomotor deficits and anxiety-like behaviors and reduced striatal neuronal loss, whereas the alanine mutations did not hinder the pathogenic actions of mHTT. In the case of the serine 421 site, the phosphomimetic substitution reduced steady-state levels of pathogenic soluble mHTT and increased turnover to improve clearance of mHTT. These studies thus identified specific structural changes in mHTT that may be responsible for pathophysiology in HD.

\section{Knock-in Huntington's disease mouse models}

Knock-in (KI) mouse models of HD consist of the human HD mutation inserted into the mouse HTT gene locus. Because the mutation is expressed in its appropriate genomic and protein context, these models are believed to more accurately represent the genetic basis of $\mathrm{HD}$ and have been used extensively to investigate the pathophysiology of HD and potential treatments ${ }^{126}$. The three KI models that have been studied the most are the Q140, $\operatorname{Hdh}(\mathrm{CAG}) 150$, and Q175 mice, although other models with varying CAG expansions, including those with 50, 92, and $111 \mathrm{CAG}$ repeats, have also been developed and studied $^{157,158}$. In the $\mathrm{Q} 140$ mice, mouse exon 1 of HTT is replaced by a mutated version of human exon $1^{127,128}$. Robust behavioral deficits as well as motor abnormalities have been

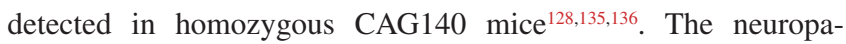
thology consists of mHTT nuclear staining and aggregates in the striatum and cortex, which become intense and widespread at only 4 months of age. The early pathology corresponds to brain regions that receive DA inputs, supporting the relationship between dopamine and HD pathology ${ }^{128,159}$. mHTT aggregates are also first seen in the striosomes, consistent with the early vulnerability of this region in humans ${ }^{137}$. These mice also show early loss of thalamic-striatal neuronal input to MSNs, which may contribute to striatal dysfunction manifest as diminished excitatory drive in the striatum ${ }^{138}$. In old age (1-2 years), CAG140 mice show late striatal neuronal loss and atrophy. Surviving neurons express loss of spines and reduced dendritic complexity. The olfactory system displays early and marked aggregate accumulation, which may be relevant to the early deficit in odor discrimination observed in patients with $\mathrm{HD}^{139,140}$.

In the $\mathrm{Hdh}(\mathrm{CAG}) 150$ model, $150 \mathrm{CAG}$ repeats were inserted into the mouse HTT but no human sequences are included ${ }^{129}$. This model shows a delayed onset of symptoms compared with CAG140 mice but exhibit motor defects, such as balance and gait abnormalities, as well as clasping and weight loss, by 40 weeks of age ${ }^{131}$. Cognitive deficits occur at around 24 weeks of $\operatorname{age}^{132}$. By 22 months, they show widespread mHTT aggregation throughout the brain and transcriptional dysregulation $^{160}$.

Interestingly, a study by Arnoux et al. (2018) ${ }^{161}$ using in vivo two-photon $\mathrm{Ca}^{2+}$ imaging in premanifest $\mathrm{Hdh}(\mathrm{CAG}) 150 \mathrm{KI}$ mice showed increased neuronal activity in the visual cortex. This finding is consistent with early signs of hyperactivity in cortical networks found in other HD models and the finding that early in HD the visual cortex is one of the first brain regions to show dysfunction ${ }^{162}$.

Side-by-side comparison of CAG140 and $\mathrm{Hdh}(\mathrm{CAG}) 150$ mice by Franich et al. (2019) ${ }^{133}$ showed that CAG140 mice exhibit earlier onset of behavioral deficits and formation of nuclear inclusions. The authors proposed that these differences may be due to an incompletely spliced HTT exon 1 transcript in the CAG140 mouse, which encodes the highly pathogenic exon 1 mHTT protein ${ }^{163,164}$ which leads to early aggregation. The very early phenotypic deficits in the Q140 mice have made them an ideal model for testing novel therapeutic interventions.

The Q175 KI mouse is a spontaneous extension of the Q140 $\mathrm{KI}^{130}$. The Q175 KI mouse shows behavioral changes, including motor, cognitive, and circadian deficits ${ }^{130}$. These mice exhibit gait abnormalities at 4 weeks of age, hypoactivity as measured in the open-field test by 4 months ${ }^{130,134}$, rotarod and climbing abnormalities at 30 weeks of age, and cognitive deficits at 12 months. mHTT aggregates are widely distributed throughout the brain, and the number of neurons containing nuclear inclusions increases with age in both the striatum and cortex ${ }^{134}$. Morphological alterations include decreased numbers of MSNs and striatal volume loss ${ }^{81}$. 
Both CAG140 and Q175 mice have been used to study synaptic changes caused by mHTT. Within the striatum, there is a decrease in burst firing in CAG140 KI mice ${ }^{142,143}$, consistent with decreases in EPSCs and increases in IPSCs, much like those found in R6/2 mice ${ }^{24,78}$. The cortex of CAG140 mice shows increased EPSC frequency ${ }^{84}$ and decreased synchrony ${ }^{87}$. Donzis et al. $(2020)^{165}$ used two-photon laser-scanning microscopy on symptomatic Q175 mice to study network circuitry in the motor cortical neurons and found that calcium transients had reduced amplitude, suggesting decreased bursting activity. In contrast, in pre-symptomatic Q175 mice, neuronal activity was increased, consistent with a switch in activity of these neurons over time.

Electrophysiological studies have shown that spontaneous GABAergic currents in striatal MSNs are increased in symptomatic Q175 mice $^{78}$ but that EPSCs in MSNs are decreased ${ }^{24,80-82}$ because of alterations in glutamatergic inputs from the cortex and thalamus ${ }^{28,78,144}$. Significant decreases in spine density of MSNs were found in Q175 mice. The increase in frequency of IPSCs combined with the decrease in frequency of EPSCs generate an imbalance in the ratio of inhibition to excitation, which is relevant for understanding phenotype progression.

This notion is supported by evidence that shows a decline in the glutamate-to-GABA ratio measured by high-performance liquid chromatography in 6-month-old Q175 mice ${ }^{141}$. Striatal interneurons-both persistent, low threshold-spiking somatostatin-expressing interneurons and fast-firing PV-expressing interneurons-are principal sources of the rise in inhibition seen in MSNs in the R6/2 and BACHD models ${ }^{166}$. Loss of excitatory inputs to MSNs, which seem to be associated with loss of dendritic spines and increased inhibitory inputs to MSNs, is exhibited by the Q175 mice.

Studies in R6/2 mice showed that in addition to an alteration of striatal MSN properties, there were changes in output regions of MSNs that may contribute to the pathophysiology of HD. Similarly, Atherton et al. showed that in Q175 mice, STN neurons have altered synaptic properties indicative of dysfunction and degeneration ${ }^{145}$. The STN is a critical component of the direct and indirect MSNs output pathways and is critical for constraining cortico-striatal activity underlying action selection $^{48,167}$. In Q175 mice, autonomous STN activity is impaired because of activation of $\mathrm{K}^{\text {ATP }}$ channels. STN neurons exhibit prolonged NMDA receptor-mediated synaptic currents due to deficient glutamate uptake, which can be rescued by NMDA receptor antagonism. At 12 months of age, about $30 \%$ of STN neurons are lost in these mice ${ }^{141}$. The STN dysfunction and neuronal loss precede striatal cell death and corticostriatal abnormalities and occur prior to the onset of major behavioral symptoms. Thus, dysfunction and degeneration of cortical and striatal neurons occur in concert with profound changes in other elements of the basal ganglia. Dysfunction within the STN is an early HD feature that may contribute to its expression and course ${ }^{145}$.
Interestingly, the availability of KI mouse models with a large range of CAG repeats $(50,92,111,140,150$, and 175 CAG repeats) has facilitated studies to establish the relationship between CAG repeat length and the changes in behavior and brain transcription that are linked to the progression of pathogenesis ${ }^{168,169}$. Similarly, Ament et al. (2017) ${ }^{170}$ used KI mice with different CAG repeats to begin to understand the molecular basis of CAG repeat instability in the striatum linked to neurodegeneration. Others have also used the KI mice to investigate the role of epigenetic changes that contribute to chromatin remodeling ${ }^{171}$ and DNA repair alterations in $\mathrm{HD}^{172,173}$.

\section{Conclusions}

The development of in vivo animal models of HD has greatly added to our understanding of the biology of HD and the molecular and cellular pathways that drive pathogenesis. One issue to consider in the different mouse models is the different forms of mHTT expressed in each. Those with fragments, such as the R6/2 mouse, may produce exaggerated phenotypes and, because the expressed protein lacks downstream regulatory sites, may lack the full range of mutant HTT gene and proteinprotein interactions. Although the BACHD model has provided important information on structural aspects of the mHTT protein that impact disease behaviors such as locomotion and anxiety, this model is unusual in that the mice gain excessive weight whereas most patients with HD generally have greatly reduced weight. Similarly, the YAC128 mice which express full-length human mHTT also exhibit weight gain. This anomaly may be unrelated to CAG repeat length and has been proposed to be due to the impact of HTT on the expression of IgF- $1^{174}$. In the KI model, the expanded human CAG repeats and human exon 1 are inserted into the mouse $H t t$ locus, so a chimera of the full-length mouse protein with the N-terminal human portion is expressed. Many aspects of the pathology and behavioral deficits in the Q140 KI mouse and the spontaneously expanded Q175 KI mouse mimic disease characteristics found in patients with HD, and importantly those phenotypes are robust. Accordingly, some have proposed that these mice may be preferable models of the disease ${ }^{133}$.

The best model is the one that is the most predictive of human disease. Unfortunately, animal models for most human neurodegenerative diseases have historically been poor at predicting which therapeutics are most likely to work in humans. However, as our understanding of the disease mechanisms of HD advances, so will the design of animal models to discover and test innovative therapeutics that may be translated into treatment to slow the onset and progression of HD.

\section{Acknowledgments}

We would like to thank Dr. Katy Claiborn (Gladstone Institute, CA), Giovanni Maki (Gladstone Institute, CA), and Dr. MarieFrancoise Chesselet (Emeritus Professor at UCLA, CA) and all members of the Finkbeiner lab. 
1. MacDonald ME, Ambrose CM, Duyao MP, et al.: A novel gene containing a trinucleotide repeat that is expanded and unstable on Huntington's disease chromosomes. Cell. 1993; 72(6): 971-83.

PubMed Abstract | Publisher Full Text

2. Vonsattel JP, DiFiglia M: Huntington disease. J Neuropathol Exp Neurol. 1998; 57(5): 369-84.

PubMed Abstract | Publisher Full Text

3. DiFiglia M, Sapp E, Chase $\mathrm{K}$, et al:: Huntingtin is a cytoplasmic protein associated with vesicles in human and rat brain neurons. Neuron. 1995; 14(5): 1075-81.

PubMed Abstract | Publisher Full Text

4. Bean L, Bayrak-Toydemir P: American College of Medical Genetics and Genomics Standards and Guidelines for Clinical Genetics Laboratories, 2014 edition: Technical standards and guidelines for Huntington disease. Genet Med. 2014; 16(12): e2.

PubMed Abstract | Publisher Full Text

5. Brocklebank D, Gayán J, Andresen JM, et al:: Repeat instability in the 27-39 CAG range of the HD gene in the Venezuelan kindreds: Counseling implications. Am J Med Genet B Neuropsychiatr Genet. 2009; 150B(3): 425-9.

PubMed Abstract | Publisher Full Text | Free Full Text

6. McNeil SM, Novelletto A, Srinidhi J, et al.: Reduced penetrance of the Huntington's disease mutation. Hum Mol Genet. 1997; 6(5): 775-9. PubMed Abstract | Publisher Full Text

7. Snell RG, MacMillan JC, Cheadle JP, et al:: Relationship between trinucleotide repeat expansion and phenotypic variation in Huntington's disease. Nat Genet. 1993; 4(4): 393-7.

PubMed Abstract | Publisher Full Text

8. Andrew SE, Goldberg YP, Kremer B, et al:: The relationship between trinucleotide (CAG) repeat length and clinical features of Huntington's disease. Nat Genet. 1993; 4(4): 398-403.

PubMed Abstract | Publisher Full Text

9. Wexler NS, Lorimer J, Porter J, et al:: Venezuelan kindreds reveal that genetic and environmental factors modulate Huntington's disease age of onset. Proc Natl Acad Sci U S A. 2004; 101(10): 3498-503.

PubMed Abstract | Publisher Full Text | Free Full Text

10. Gayán J, Brocklebank D, Andresen JM, et al:: Genomewide linkage scan reveals novel loci modifying age of onset of Huntington's disease in the Venezuelan HD kindreds. Genet Epidemiol. 2008; 32(5): 445-53. PubMed Abstract | Publisher Full Text

11. Moss DJH, Pardiñas AF, Langbehn D, et al:: Identification of genetic variants associated with Huntington's disease progression: A genome-wide association study. Lancet Neurol. 2017; 16(9): 701-11. PubMed Abstract | Publisher Full Text

12. Genetic Modifiers of Huntington's Disease (GeM-HD) Consortium: Identification of Genetic Factors that Modify Clinical Onset of Huntington's Disease. Cell. 2015; 162(3): 516-26.

PubMed Abstract | Publisher Full Text | Free Full Text |

Faculty Opinions Recommendation

13. Goold R, Flower M, Moss DH, et al: FAN1 modifies Huntington's disease progression by stabilizing the expanded HTT CAG repeat. Hum Mol Genet. 2019; 28(4): 650-61.

PubMed Abstract | Publisher Full Text | Free Full Text |

Faculty Opinions Recommendation

14. Anderson KE, Marder KS: An overview of psychiatric symptoms in Huntington's disease. Curr Psychiatry Rep. 2001; 3(5): 379-88. PubMed Abstract | Publisher Full Text

15. Paoli RA, Botturi A, Ciammola A, et al.: Neuropsychiatric Burden in Huntington's Disease. Brain Sci. 2017; 7(6): 67.

PubMed Abstract | Publisher Full Text | Free Full Text

16. Sanberg PR, Fibiger HC, Mark RF: Body weight and dietary factors in Huntington's disease patients compared with matched controls. Med J Aust. 1981; 1(8): 407-9. PubMed Abstract | Publisher Full Text

17. Morton AJ, Wood NI, Hastings MH, et al:: Disintegration of the sleep-wake cycle and circadian timing in Huntington's disease. J Neurosci. 2005; 25(1): 157-63. PubMed Abstract | Publisher Full Text | Free Full Text

18. Ross CA, Tabrizi SJ: Huntington's disease: From molecular pathogenesis to clinical treatment. Lancet Neurol. 2011; 10(1): 83-98. PubMed Abstract | Publisher Full Text

19. Myers RH: Huntington's disease genetics. NeuroRx. 2004; 1(2): 255-62. PubMed Abstract | Publisher Full Text | Free Full Text

20. Roos RA: Huntington's disease: A clinical review. Orphanet J Rare Dis. 2010; 5: 40.

PubMed Abstract | Publisher Full Text | Free Full Text

21. Crossman AR: Functional anatomy of movement disorders. J Anat. 2000; 196(Pt 4): 519-25.

PubMed Abstract | Publisher Full Text | Free Full Text

22. Graybiel AM, Aosaki T, Flaherty AW, et al:: The basal ganglia and adaptive motor control. Science. 1994; 265(5180): 1826-31.

PubMed Abstract | Publisher Full Text

23. Walker FO: Huntington's Disease. Semin Neurol. 2007; 27(2): 143-50.

PubMed Abstract | Publisher Full Text

24. Cepeda C, Hurst RS, Calvert CR, et al: Transient and Progressive Electrophysiological Alterations in the Corticostriatal Pathway in a Mouse

Model of Huntington's Disease. J Neurosci. 2003; 23(3): 961-9.

PubMed Abstract | Publisher Full Text | Free Full Text

25. DiProspero NA, Chen EY, Charles V, et al:: Early changes in Huntington's disease patient brains involve alterations in cytoskeletal and synaptic elements. J Neurocytol. 2004; 33(5): 517-33.

PubMed Abstract | Publisher Full Text

26. André VM, Cepeda $\mathrm{C}$, Venegas $\mathrm{A}$, et al.: Altered cortical glutamate receptor function in the R6/2 model of Huntington's disease. J Neurophysiol. 2006; 95(4): 2108-19.

PubMed Abstract | Publisher Full Text

27. Graham RK, Pouladi MA, Joshi $\mathrm{P}$, et al:: Differential susceptibility to excitotoxic stress in YAC128 mouse models of Huntington disease between initiation and progression of disease. J Neurosci. 2009; 29(7): 2193-204. PubMed Abstract | Publisher Full Text | Free Full Text

28. Joshi PR, Wu NP, André VM, et al:: Age-dependent alterations of corticostriatal activity in the YAC128 mouse model of Huntington disease. $J$ Neurosci. 2009; 29(8): 2414-27.

PubMed Abstract | Publisher Full Text | Free Full Text

29. Milnerwood AJ, Gladding CM, Pouladi MA, et al:: Early increase in extrasynaptic NMDA receptor signaling and expression contributes to phenotype onset in Huntington's disease mice. Neuron. 2010; 65(2): 178-90. PubMed Abstract | Publisher Full Text | Faculty Opinions Recommendation

30. Kipps CM, Duggins AJ, Mahant N, et al.: Progression of structural neuropathology in preclinical Huntington's disease: A tensor based morphometry study. J Neurol Neurosurg Psychiatry. 2005; 76(5): 650-5. PubMed Abstract | Publisher Full Text | Free Full Text

31. Starling AJ, André VM, Cepeda C, et al:: Alterations in N-methyl-D-aspartate receptor sensitivity and magnesium blockade occur early in development in the R6/2 mouse model of Huntington's disease. J Neurosci Res. 2005; 82(3): 377-86.

PubMed Abstract | Publisher Full Text

32. de La Monte SM, Vonsattel JP, Richardson EP Jr: Morphometric demonstration of atrophic changes in the cerebral cortex, white matter, and neostriatum in Huntington's disease. J Neuropathol Exp Neurol. 1988; 47(5): 516-25. PubMed Abstract | Publisher Full Text

33. Ferrante RJ, Kowall NW, Richardson EP Jr: Proliferative and degenerative changes in striatal spiny neurons in Huntington's disease: A combined study using the section-Golgi method and calbindin D28k immunocytochemistry. J Neurosci. 1991; 11(12): 3877-87.

PubMed Abstract | Publisher Full Text | Free Full Text

34. Klapstein GJ, Fisher RS, Zanjani H, et al.: Electrophysiological and morphological changes in striatal spiny neurons in R6/2 Huntington's disease transgenic mice. J Neurophysiol. 2001; 86(6): 2667-77. PubMed Abstract | Publisher Full Text

35. Laforet GA, Sapp E, Chase K, et al.: Changes in Cortical and Striatal Neurons Predict Behavioral and Electrophysiological Abnormalities in a Transgenic Murine Model of Huntington's Disease. J Neurosci. 2001; 21(23): 9112-23. PubMed Abstract | Publisher Full Text | Free Full Text

36. Marco S, Giralt A, Petrovic MM, et al.: Suppressing aberrant GluN3A expression rescues synaptic and behavioral impairments in Huntington's disease models. Nat Med. 2013; 19(8): 1030-8.

PubMed Abstract | Publisher Full Text | Free Full Text

37. Spires TL, Grote HE, Garry S, et al.: Dendritic spine pathology and deficits in experience-dependent dendritic plasticity in R6/1 Huntington's disease transgenic mice. Eur J Neurosci. 2004; 19(10): 2799-807. PubMed Abstract | Publisher Full Text

38. Wu J, Ryskamp DA, Liang X, et al.: Enhanced Store-Operated Calcium Entry Leads to Striatal Synaptic Loss in a Huntington's Disease Mouse Model. J Neurosci. 2016; 36(1): 125-41.

PubMed Abstract | Publisher Full Text | Free Full Text

39. Cepeda C, Wu N, André VM, et al.: The corticostriatal pathway in Huntington's disease. Prog Neurobiol. 2007; 81(5-6): 253-71. PubMed Abstract | Publisher Full Text | Free Full Text

40. Tan B, Shishegar R, Poudel GR, et al:: Cortical morphometry and neural dysfunction in Huntington's disease: A review. Eur J Neurol. 2021; 28(4): 1406-19.

PubMed Abstract | Publisher Full Text | Faculty Opinions Recommendation

41. Langley C, Gregory S, Osborne-Crowley K, et al.: Fronto-striatal circuits for cognitive flexibility in far from onset Huntington's disease: Evidence from the Young Adult Study. J Neurol Neurosurg Psychiatr. 2021; 92(2): 143-9. PubMed Abstract | Publisher Full Text | Free Full Text Faculty Opinions Recommendation 
42. André VM, Cepeda C, Fisher YE, et al:: Differential electrophysiological changes in striatal output neurons in Huntington's disease. J Neurosci. 2011; 31(4): 1170-82.

PubMed Abstract | Publisher Full Text | Free Full Text

43. Wang N, Gray M, Lu XH, et al.: Neuronal targets for reducing mutant huntingtin expression to ameliorate disease in a mouse model of Huntington's disease. Nat Med. 2014; 20(5): 536-41. PubMed Abstract | Publisher Full Text | Free Full Text | Faculty Opinions Recommendation

44. Rosas HD, Koroshetz WJ, Chen YI, et al:: Evidence for more widespread cerebral pathology in early HD: An MRI-based morphometric analysis. Neurology. 2003; 60(10): 1615-20.

PubMed Abstract | Publisher Full Text

45. Rosas HD, Hevelone ND, Zaleta AK, et al:: Regional cortical thinning in preclinical Huntington disease and its relationship to cognition. Neurology. 2005; 65(5): 745-7.

PubMed Abstract | Publisher Full Text

46. Rosas HD, Tuch DS, Hevelone ND, et al:: Diffusion tensor imaging in presymptomatic and early Huntington's disease: Selective white matter pathology and its relationship to clinical measures. Mov Disord. 2006; 21(9) 1317-25.

PubMed Abstract | Publisher Full Text

47. Estrada-Sánchez AM, Rebec GV: Role of cerebral cortex in the neuropathology of Huntington's disease. Front Neural Circuits. 2013; 7: 19. PubMed Abstract | Publisher Full Text | Free Full Text

48. Albin RL, Young AB, Penney JB: The functional anatomy of basal ganglia disorders. Trends Neurosci. 1989; 12(10): 366-75. PubMed Abstract | Publisher Full Text

49. Gerfen CR, Engber TM, Mahan LC, et al:: D1 and D2 dopamine receptorregulated gene expression of striatonigral and striatopallidal neurons. Science. 1990; 250(4986): 1429-32.

PubMed Abstract | Publisher Full Text

50. Reiner A, Albin RL, Anderson KD, et al.: Differential loss of striatal projection neurons in Huntington disease. Proc Natl Acad Sci U S A. 1988; 85(15): 5733-7. PubMed Abstract | Publisher Full Text | Free Full Text

51. Albin RL, Reiner A, Anderson KD, et al.: Preferential loss of striato-external pallidal projection neurons in presymptomatic Huntington's disease. Ann Neurol. 1992; 31(4): 425-30.

PubMed Abstract | Publisher Full Text

52. Holley SM, Kamdjou T, Reidling JC, et al:: Therapeutic effects of stem cells in rodent models of Huntington's disease: Review and electrophysiological findings. CNS Neurosci Ther. 2018; 24(4): 329-42. PubMed Abstract | Publisher Full Text | Free Full Text | Faculty Opinions Recommendation

53. Zuccato C, Ciammola A, Rigamonti D, et al:: Loss of huntingtin-mediated BDNF gene transcription in Huntington's disease. Science. 2001; 293(5529): 493-8. PubMed Abstract | Publisher Full Text

54. Zuccato $\mathrm{C}$, Cattaneo $\mathrm{E}$ : Role of brain-derived neurotrophic factor in Huntington's disease. Prog Neurobiol. 2007; 81(5-6): 294-330. PubMed Abstract | Publisher Full Text

55. Gerfen CR, Surmeier DJ: Modulation of striatal projection systems by dopamine. Annu Rev Neurosci. 2011; 34: 441-66. PubMed Abstract | Publisher Full Text | Free Full Text

56. Kravitz AV, Freeze BS, Parker PRL, et al:: Regulation of parkinsonian motor behaviours by optogenetic control of basal ganglia circuitry. Nature. 2010; 466(7306): 622-6.

PubMed Abstract | Publisher Full Text | Free Full Text | Faculty Opinions Recommendation

57. Cepeda C, Murphy KPS, Parent M, et al:: The role of dopamine in Huntington's disease. Prog Brain Res. 2014; 211: 235-54. PubMed Abstract | Publisher Full Text | Free Full Text

58. Bozzi $Y$, Borrelli E: Dopamine in neurotoxicity and neuroprotection: What do $D_{2}$ receptors have to do with it? Trends Neurosci. 2006; 29(3): 167-74. receptors have to do with it? Trends $N$
PubMed Abstract | Publisher Full Text

59. Cepeda C, Colwell CS, Itri JN, et al:: Dopaminergic modulation of NMDA-induced whole cell currents in neostriatal neurons in slices: Contribution of calcium conductances. J Neurophysiol. 1998; 79(1): 82-94. PubMed Abstract | Publisher Full Text

60. Wang JQ, Chen Q, Wang X, et al.: Dysregulation of mitochondrial calcium signaling and superoxide flashes cause mitochondrial genomic DNA damage in Huntington disease. J Biol Chem. 2013; 288(5): 3070-84. PubMed Abstract | Publisher Full Text | Free Full Text

61. Tang TS, Chen X, Liu J, et al:: Dopaminergic signaling and striatal neurodegeneration in Huntington's disease. J Neurosci. 2007; 27(30): 7899-910.

PubMed Abstract | Publisher Full Text | Free Full Text

62. Paoletti $\mathrm{P}$, Vila I, Rifé $\mathrm{M}$, et al.: Dopaminergic and glutamatergic signaling crosstalk in Huntington's disease neurodegeneration: The role of p25/cyclin-dependent kinase 5. J Neurosci. 2008; 28(40): 10090-101. PubMed Abstract | Publisher Full Text | Free Full Text

63. Charvin D, Roze E, Perrin V, et al.: Haloperidol protects striatal neurons from dysfunction induced by mutated huntingtin in vivo. Neurobiol Dis. 2008; 29(1): 22-9. PubMed Abstract | Publisher Full Text

64. Richfield EK, O'Brien CF, Eskin T, et al.: Heterogeneous dopamine receptor changes in early and late Huntington's disease. Neurosci Lett. 1991; 132(1): 121-6.

PubMed Abstract | Publisher Full Text

65. van Oostrom JCH, Dekker M, Willemsen ATM, et al.: Changes in striatal dopamine D2 receptor binding in pre-clinical Huntington's disease. Eur $J$ Neurol. 2009; 16(2): 226-31.

PubMed Abstract | Publisher Full Text

66. Weeks RA, Piccini P, Harding AE, et al:: Striatal D1 and D2 dopamine receptor loss in asymptomatic mutation carriers of Huntington's disease. Ann Neurol. 1996; 40(1): 49-54.

PubMed Abstract | Publisher Full Text

67. Cha JH, Kosinski CM, Kerner JA, et al:: Altered brain neurotransmitter receptors in transgenic mice expressing a portion of an abnormal human huntington disease gene. Proc Natl Acad Sci U S A. 1998; 95(11): 6480-5. PubMed Abstract | Publisher Full Text | Free Full Text

68. Bibb JA, Yan Z, Svenningsson P, et al:: Severe deficiencies in dopamine signaling in presymptomatic Huntington's disease mice. Proc Natl Acad Sci U $S$ A. 2000; 97(12): 6809-14.

PubMed Abstract | Publisher Full Text | Free Full Text

69. Ariano MA, Aronin N, DiFiglia M, et al:: Striatal neurochemical changes in transgenic models of Huntington's disease. J Neurosci Res. 2002; 68(6): 716-29.

PubMed Abstract | Publisher Full Text

70. Pouladi MA, Stanek LM, Xie Y, et al:: Marked differences in neurochemistry and aggregates despite similar behavioural and neuropathological features of Huntington disease in the full-length BACHD and YAC128 mice. Hum Mol Genet. 2012; 21(10): 2219-32.

PubMed Abstract | Publisher Full Text

71. Bäckman L, Farde L: Dopamine and cognitive functioning: Brain imaging findings in Huntington's disease and normal aging. Scand J Psychol. 2001; 42(3): 287-96.

PubMed Abstract | Publisher Full Text

72. Sathasivam K, Hobbs $C$, Mangiarini L, et al.: Transgenic models of Huntington's disease. Philos Trans R Soc Lond B Biol Sc. 1999; 354(1386): 963-9. PubMed Abstract | Publisher Full Text | Free Full Text

73. Mangiarini L, Sathasivam K, Seller M, et al:: Exon 1 of the $H D$ Gene with an Expanded CAG Repeat Is Sufficient to Cause a Progressive Neurologica Phenotype in Transgenic Mice. Cell. 1996; 87(3): 493-506. PubMed Abstract | Publisher Full Text

74. Li JY, Popovic N, Brundin P: The use of the R6 transgenic mouse models of Huntington's disease in attempts to develop novel therapeutic strategies. NeuroRx. 2005; 2(3): 447-64.

PubMed Abstract | Publisher Full Text | Free Full Text

75. Carter RJ, Lione LA, Humby T, et al:: Characterization of Progressive Motor Deficits in Mice Transgenic for the Human Huntington's Disease Mutation. $J$ Neurosci. 1999; 19(8): 3248-57.

PubMed Abstract | Publisher Full Text | Free Full Text

76. Gourfinkel-An I, Parain K, Hartmann A, et al:: Changes in GAD mRNA expression evidenced by in situ hybridization in the brain of $\mathrm{R} 6 / 2$ transgenic mice. J Neurochem. 2003; 86(6): 1369-78. PubMed Abstract | Publisher Full Text

77. Ariano MA, Cepeda C, Calvert CR, et al:: Striatal potassium channel dysfunction in Huntington's disease transgenic mice. J Neurophysiol. 2005; 93(5): 2565-74. PubMed Abstract | Publisher Full Text

78. Cepeda C, Starling AJ, Wu N, et al:: Increased GABAergic function in mouse models of Huntington's disease: Reversal by BDNF. J Neurosci Res. 2004; 78(6): 855-67.

PubMed Abstract | Publisher Full Text

79. Dvorzhak A, Semtner M, Faber DS, et al:: Tonic mGluR5/CB1-dependent suppression of inhibition as a pathophysiological hallmark in the striatum of mice carrying a mutant form of huntingtin. J Physiol. 2013; 591(4): 1145-66. PubMed Abstract | Publisher Full Text | Free Full Text

80. Cummings DM, Cepeda C, Levine MS: Alterations in striatal synaptic transmission are consistent across genetic mouse models of Huntington's disease. ASN Neuro. 2010; 2(3): e00036. PubMed Abstract | Publisher Full Text | Free Full Text

81. Heikkinen $\mathrm{T}$, Lehtimäki K, Vartiainen $\mathrm{N}$, et al.: Characterization of neurophysiological and behavioral changes, MRI brain volumetry and 1H MRS in zQ175 knock-in mouse model of Huntington's disease. PLOS One. 2012; 7(12): e50717. PubMed Abstract | Publisher Full Text | Free Full Text

82. Indersmitten $\mathrm{T}$, Tran $\mathrm{CH}$, Cepeda $\mathrm{C}$, et al:: Altered excitatory and inhibitory inputs to striatal medium-sized spiny neurons and cortical pyramidal neurons in the Q175 mouse model of Huntington's disease. J Neurophysiol. 2015; 113(7): 2953-66. PubMed Abstract | Publisher Full Text | Free Full Text

83. Barry J, Akopian G, Cepeda C, et al.: Striatal Direct and Indirect Pathway 
Output Structures Are Differentially Altered in Mouse Models of Huntington's Disease. J Neurosci. 2018; 38(20): 4678-94.

PubMed Abstract | Publisher Full Text | Free Full Text |

Faculty Opinions Recommendation

84. Cummings DM, André VM, Uzgil BO, et al:: Alterations in cortical excitation and inhibition in genetic mouse models of Huntington's disease. J Neurosci. 2009; 29(33): 10371-86.

PubMed Abstract | Publisher Full Text | Free Full Text

85. Burgold J, Schulz-Trieglaff EK, Voelkl K, et al.: Cortical circuit alterations precede motor impairments in Huntington's disease mice. Sci Rep. 2019; 9(1): 6634.

PubMed Abstract | Publisher Full Text | Free Full Text |

Faculty Opinions Recommendation

86. Fernández-García S, Conde-Berriozabal S, García-García E, et al.: M2 cortex-dorsolateral striatum stimulation reverses motor symptoms and synaptic deficits in Huntington's disease. eLife. 2020; 9: e57017.

PubMed Abstract | Publisher Full Text | Free Full Text |

Faculty Opinions Recommendation

87. Walker AG, Miller BR, Fritsch JN, et al: Altered information processing in the prefrontal cortex of Huntington's disease mouse models. J Neurosci. 2008; 28(36): 8973-82.

PubMed Abstract | Publisher Full Text | Free Full Text

88. Hong SL, Cossyleon D, Hussain WA, et al.: Dysfunctional behavioral modulation of corticostriatal communication in the R6/2 mouse model of Huntington's disease. PLoS One. 2012; 7(10): e47026.

PubMed Abstract | Publisher Full Text | Free Full Text

89. Callahan JW, Abercrombie ED: Age-dependent alterations in the cortical entrainment of subthalamic nucleus neurons in the YAC128 mouse model of Huntington's disease. Neurobiol Dis. 2015; 78: 88-99. PubMed Abstract | Publisher Full Text

90. Estrada-Sánchez AM, Montiel T, Segovia J, et al.: Glutamate toxicity in the striatum of the R6/2 Huntington's disease transgenic mice is age-dependent and correlates with decreased levels of glutamate transporters. Neurobiol Dis. 2009; 34(1): 78-86.

PubMed Abstract | Publisher Full Text

91. Estrada-Sánchez AM, Castro D, Portillo-Ortiz K, et al:: Complete but not partial inhibition of glutamate transporters exacerbates cortical excitability in the R6/2 mouse model of Huntington's disease. CNS Neurosci Ther. 2019 25(4): 509-18.

PubMed Abstract | Publisher Full Text | Free Full Text |

Faculty Opinions Recommendation

92. Arzberger T, Krampfl K, Leimgruber S, et al.: Changes of NMDA receptor subunit (NR1, NR2B) and glutamate transporter (GLT1) mRNA expression in Huntington's disease--an in situ hybridization study. J Neuropathol Exp Neurol. 1997; 56(4): 440-54.

PubMed Abstract | Publisher Full Text

93. Liévens JC, Woodman B, Mahal A, et al:: Impaired glutamate uptake in the R6 Huntington's disease transgenic mice. Neurobiol Dis. 2001; 8(5): 807-21. PubMed Abstract | Publisher Full Text

94. Behrens PF, Franz P, Woodman B, et al:: Impaired glutamate transport and glutamate-glutamine cycling: Downstream effects of the Huntington mutation. Brain. 2002; 125(Pt 8): 1908-22.

PubMed Abstract | Publisher Full Text

95. Hassel B, Tessler S, Faull RLM, et al.: Glutamate uptake is reduced in prefronta cortex in Huntington's disease. Neurochem Res. 2008; 33(2): 232-7. PubMed Abstract | Publisher Full Text

96. Faideau M, Kim J, Cormier $\mathrm{K}$, et al:: In vivo expression of polyglutamineexpanded huntingtin by mouse striatal astrocytes impairs glutamate transport: A correlation with Huntington's disease subjects. Hum Mol Genet. 2010; 19(15): 3053-67.

PubMed Abstract | Publisher Full Text | Free Full Text

97. Cepeda-Prado E, Popp S, Khan U, et al.: R6/2 Huntington's disease mice develop early and progressive abnormal brain metabolism and seizures. $J$ Neurosci. 2012; 32(19): 6456-67.

PubMed Abstract | Publisher Full Text | Free Full Text

98. Danbolt NC: Glutamate uptake. Prog Neurobiol. 2001; 65(1): 1-105. PubMed Abstract | Publisher Full Text

99. Skotte NH, Andersen JV, Santos A, et al.: Integrative Characterization of the R6/2 Mouse Model of Huntington's Disease Reveals Dysfunctional Astrocyte Metabolism. Cell Rep. 2018; 23(7): 2211-24.

PubMed Abstract | Publisher Full Text | Faculty Opinions Recommendation

100. Khakh BS, Beaumont V, Cachope R, et al.: Unravelling and Exploiting Astrocyte Dysfunction in Huntington's Disease. Trends Neurosci. 2017; 40(7): 422-37. PubMed Abstract | Publisher Full Text | Free Full Text

101. Reidling JC, Relaño-Ginés A, Holley SM, et al.: Human Neural Stem Cell Transplantation Rescues Functional Deficits in R6/2 and Q140 Huntington's Disease Mice. Stem Cell Reports. 2018; 10(1): 58-72. PubMed Abstract | Publisher Full Text | Free Full Text | Faculty Opinions Recommendation

102. Guo Q, Huang B, Cheng J, et al.: The cryo-electron microscopy structure of huntingtin. Nature. 2018; 555(7694): 117-20.

PubMed Abstract | Publisher Full Text | Free Full Text

Faculty Opinions Recommendation

103. Andrade MA, Bork P: HEAT repeats in the Huntington's disease protein. Nat Genet. 1995; 11(2): 115-6. PubMed Abstract | Publisher Full Text

104. Ehrnhoefer DE, Butland SL, Pouladi MA, et al:: Mouse models of Huntington disease: Variations on a theme. Dis Model Mech. 2009; 2(3-4): 123-9. PubMed Abstract | Publisher Full Text | Free Full Text

105. Cattaneo $E$, Zuccato $C$, Tartari M: Normal huntingtin function: An alternative approach to Huntington's disease. Nat Rev Neurosci. 2005; 6(12): 919-30. PubMed Abstract | Publisher Full Text

106. Ehrnhoefer DE, Sutton L, Hayden MR: Small changes, big impact: Posttranslational modifications and function of huntingtin in Huntington disease. Neuroscientist. 2011; 17(5): 475-92. PubMed Abstract | Publisher Full Text | Free Full Text

107. Schilling G, Becher MW, Sharp AH, et al:: Intranuclear inclusions and neuritic aggregates in transgenic mice expressing a mutant $\mathrm{N}$-terminal fragment of huntingtin. Hum Mol Genet. 1999; 8(3): 397-407. PubMed Abstract | Publisher Full Text

108. Yu ZX, Li SH, Evans J, et al:: Mutant Huntingtin Causes Context-Dependent Neurodegeneration in Mice with Huntington's Disease. J Neurosci.. 2003; 23(6): 2193-202.

PubMed Abstract | Publisher Full Text | Free Full Text

109. Gardian G, Browne SE, Choi DK, et al:: Neuroprotective effects of phenylbutyrate in the N171-82Q transgenic mouse model of Huntington's disease. J Biol Chem. 2005; 280(1): 556-63. PubMed Abstract | Publisher Full Text

110. Li Q, Li G, Wu D, et al.: Resting-state functional MRI reveals altered brain connectivity and its correlation with motor dysfunction in a mouse model of Huntington's disease. Sci Rep. 2017; 7: 16742.

Publisher Full Text

111. Wolf RC, Sambataro F, Vasic N, et al:: Abnormal resting-state connectivity of motor and cognitive networks in early manifest Huntington's disease. Psychol Med. 2014; 44(15): 3341-56. PubMed Abstract | Publisher Full Text

112. Harrington DL, Rubinov M, Durgerian S, et al:: Network topology and functional connectivity disturbances precede the onset of Huntington's disease. Brain. 2015; 138(Pt 8): 2332-46. PubMed Abstract | Publisher Full Text | Free Full Text

113. Koenig KA, Lowe MJ, Harrington DL, et al:: Functional connectivity of primary motor cortex is dependent on genetic burden in prodromal Huntington disease. Brain Connect. 2014; 4(7): 535-46. PubMed Abstract | Publisher Full Text | Free Full Text

114. Dumas EM, van den Bogaard SJA, Hart EP, et al.: Reduced functional brain connectivity prior to and after disease onset in Huntington's disease. Neuroimage Clin. 2013; 2: 377-84. PubMed Abstract | Publisher Full Text | Free Full Text

115. van den Stock J, de Winter FL, Ahmad R, et al.: Functional brain changes underlying irritability in premanifest Huntington's disease. Hum Brain Mapp. 2015; 36(7): 2681-90.

PubMed Abstract | Publisher Full Text | Free Full Text

116. Sánchez-Castañeda C, de Pasquale F, Caravasso CF, et al.: Resting-state connectivity and modulated somatomotor and default-mode networks in Huntington disease. CNS Neurosci Ther. 2017; 23(6): 488-97. PubMed Abstract | Publisher Full Text | Free Full Text

117. Slow EJ, van Raamsdonk J, Rogers D, et al.: Selective striatal neuronal loss in a YAC128 mouse model of Huntington disease. Hum Mol Genet. 2003; 12(13): 1555-67.

PubMed Abstract | Publisher Full Text

118. Hodgson JG, Agopyan N, Gutekunst CA, et al:: A YAC Mouse Model for Huntington's Disease with Full-Length Mutant Huntingtin, Cytoplasmic Toxicity, and Selective Striatal Neurodegeneration. Neuron. 1999; 23(1): 181Toxicit PubMed Abstract | Publisher Full Text

119. van Raamsdonk JM, Pearson J, Slow EJ, et al.: Cognitive dysfunction precedes neuropathology and motor abnormalities in the YAC128 mouse model of Huntington's disease. J Neurosci. 2005; 25(16): 4169-80. PubMed Abstract | Publisher Full Text | Free Full Text

120. Gray M, Shirasaki DI, Cepeda C, et al:: Full-length human mutant huntingtin with a stable polyglutamine repeat can elicit progressive and selective neuropathogenesis in BACHD mice. J Neurosci. 2008; 28(24): 6182-95. PubMed Abstract | Publisher Full Text | Free Full Text

121. Menalled L, El-Khodor BF, Patry M, et al:: Systematic behavioral evaluation of Huntington's disease transgenic and knock-in mouse models. Neurobiol Dis. 2009; 35(3): 319-36.

PubMed Abstract | Publisher Full Text | Free Full Text

122. Hult Lundh S, Nilsson N, Soylu R, et al.: Hypothalamic expression of mutant huntingtin contributes to the development of depressive-like behavior in the BAC transgenic mouse model of Huntington's disease. Hum Mol Genet. 2013; 22(17): 3485-97.

PubMed Abstract | Publisher Full Text 
123. Spampanato J, Gu X, Yang XW, et al.: Progressive synaptic pathology of motor cortical neurons in a BAC transgenic mouse model of Huntington's disease. Neuroscience. 2008; 157(3): 606-20.

PubMed Abstract | Publisher Full Text | Free Full Text

124. Estrada-Sánchez AM, Burroughs CL, Cavaliere S, et al:: Cortical efferents lacking mutant huntingtin improve striatal neuronal activity and behavior in a conditional mouse model of Huntington's disease. J Neurosci. 2015; 35(10): $4440-51$.

PubMed Abstract | Publisher Full Text | Free Full Text

125. W Wood TE, Barry J, Yang Z, et al:: Mutant huntingtin reduction in astrocytes slows disease progression in the BACHD conditional Huntington's disease mouse model. Hum Mol Genet. 2019; 28(3): 487-500. PubMed Abstract | Publisher Full Text | Free Full Text | Faculty Opinions Recommendation

126. Menalled LB: Knock-in mouse models of Huntington's disease. NeuroRx. 2005; 2(3): 465-70. PubMed Abstract | Publisher Full Text | Free Full Text

127. Hickey MA, Chesselet MF: Apoptosis in Huntington's disease. Prog Neuropsychopharmacol Biol Psychiatry. 2003; 27(2): 255-65. PubMed Abstract | Publisher Full Text

128. Menalled LB, Sison JD, Dragatsis I, et al.: Time course of early motor and neuropathological anomalies in a knock-in mouse model of Huntington's disease with 140 CAG repeats. J Comp Neurol. 2003; 465(1): 11-26. PubMed Abstract | Publisher Full Text

129. Lin $\mathrm{CH}$, Tallaksen-Greene S, Chien WM, et al:: Neurological abnormalities in a knock-in mouse model of Huntington's disease. Hum Mol Genet. 2001; 10(2): $137-44$.

PubMed Abstract | Publisher Full Text

130. Menalled LB, Kudwa AE, Miller S, et al.: Comprehensive behavioral and molecular characterization of a new knock-in mouse model of Huntington's disease: ZQ175. PLoS One. 2012; 7(12): e49838. PubMed Abstract | Publisher Full Text | Free Full Text

131. Heng MY, Tallaksen-Greene SJ, Detloff PJ, et al:: Longitudinal evaluation of the Hdh(CAG)150 knock-in murine model of Huntington's disease. J Neurosci. 2007; 27(34): 8989-98. PubMed Abstract | Publisher Full Text | Free Full Text

132. Brooks SP, Betteridge H, Trueman RC, et al.: Selective extra-dimensional set shifting deficit in a knock-in mouse model of Huntington's disease. Brain Res Bull. 2006; 69(4): 452-7. PubMed Abstract | Publisher Full Text

133. Franich NR, Hickey MA, Zhu C, et al:: Phenotype onset in Huntington's disease knock-in mice is correlated with the incomplete splicing of the mutant huntingtin gene. J Neurosci Res. 2019; 97(12): 1590-605 PubMed Abstract | Publisher Full Text | Free Full Text | Faculty Opinions Recommendation

134. Peng Q, Wu B, Jiang M, et al.: Characterization of Behavioral, Neuropathological, Brain Metabolic and Key Molecular Changes in zQ175 Knock-In Mouse Model of Huntington's Disease. PLoS One. 2016; 11(2): e0148839. PubMed Abstract | Publisher Full Text | Free Full Text

135. Dorner JL, Miller BR, Barton SJ, et al:: Sex differences in behavior and striatal ascorbate release in the 140 CAG knock-in mouse model of Huntington's disease. Behav Brain Res. 2007; 178(1): 90-7. PubMed Abstract | Publisher Full Text | Free Full Text

136. Rising AC, Xu J, Carlson A, et al.: Longitudinal behavioral, cross-sectional transcriptional and histopathological characterization of a knock-in mouse model of Huntington's disease with 140 CAG repeats. Exp Neurol. 2011; 228(2): 173-82.

PubMed Abstract | Publisher Full Text | Free Full Text

137. Lerner RP, Trejo Martinez LDCG, Zhu C, et al.: Striatal atrophy and dendritic alterations in a knock-in mouse model of Huntington's disease. Brain Res Bull. 2012; 87(6): 571-8. PubMed Abstract | Publisher Full Text | Free Full Text

138. Deng YP, Wong T, Bricker-Anthony C, et al.: Loss of corticostriatal and thalamostriatal synaptic terminals precedes striatal projection neuron pathology in heterozygous Q140 Huntington's disease mice. Neurobiol Dis. 2013; 60: 89-107. PubMed Abstract | Publisher Full Text | Free Full Text

139. Lazic SE, Goodman AOG, Grote HE, et al.: Olfactory abnormalities in Huntington's disease: Decreased plasticity in the primary olfactory cortex of $\mathrm{R} 6 / 1$ transgenic mice and reduced olfactory discrimination in patients. Brain Res. 2007; 1151: 219-26. PubMed Abstract | Publisher Full Text

140. Bylsma FW, Moberg PJ, Doty RL, et al.: Odor identification in Huntington's disease patients and asymptomatic gene carriers. J Neuropsychiatry Clin Neurosci. 1997; 9(4): 598-600. PubMed Abstract | Publisher Full Text

141. Smith GA, Rocha EM, McLean JR, et al.: Progressive axonal transport and synaptic protein changes correlate with behavioral and neuropathological abnormalities in the heterozygous Q175 KI mouse model of Huntington's disease. Hum Mol Genet. 2014; 23(17): 4510-27. PubMed Abstract | Publisher Full Text

142. Miller BR, Walker AG, Shah AS, et al.: Dysregulated information processing by medium spiny neurons in striatum of freely behaving mouse models of Huntington's disease. J Neurophysiol. 2008; 100(4): 2205-16. PubMed Abstract | Publisher Full Text | Free Full Text

143. Miller J, Arrasate M, Brooks E, et al.: Identifying polyglutamine protein species in situ that best predict neurodegeneration. Nat Chem Biol. 2011; 7(12): 925-34. PubMed Abstract | Publisher Full Text | Free Full Text

144. Kolodziejczyk K, Raymond LA: Differential changes in thalamic and cortical excitatory synapses onto striatal spiny projection neurons in a Huntington disease mouse model. Neurobiol Dis. 2016; 86: 62-74. PubMed Abstract | Publisher Full Text

145. Atherton JF, Mclver EL, Mullen MR, et al:: Early dysfunction and progressive degeneration of the subthalamic nucleus in mouse models of Huntington's disease. eLife. 2016; 5: e21616.

PubMed Abstract | Publisher Full Text | Free Full Text

146. Miller BR, Bezprozvanny I: Corticostriatal circuit dysfunction in Huntington's disease: Intersection of glutamate, dopamine and calcium. Future Neurol. 2010; 5(5): 735-56

PubMed Abstract | Publisher Full Text | Free Full Text

147. Pancani T, Foster DJ, Moehle MS, et al:: Allosteric activation of M4 muscarinic receptors improve behavioral and physiological alterations in early symptomatic YAC128 mice. Proc Natl Acad Sci U S A. 2015; 112(45): 14078-83. PubMed Abstract | Publisher Full Text | Free Full Text

148. Al-Gharaibeh A, Culver R, Stewart AN, et al.: Induced Pluripotent Stem CellDerived Neural Stem Cell Transplantations Reduced Behavioral Deficits and Ameliorated Neuropathological Changes in YAC128 Mouse Model of Huntington's Disease. Front Neurosci. 2017; 11: 628. PubMed Abstract | Publisher Full Text | Free Full Text

149. Dey ND, Bombard MC, Roland BP, et al:: Genetically engineered mesenchymal stem cells reduce behavioral deficits in the YAC 128 mouse model of Huntington's disease. Behav Brain Res. 2010; 214(2): 193-200. PubMed Abstract | Publisher Full Text

150. Serrano-Sanchez JA, Lera-Navarro A, Dorado-García C, et al:: Contribution of individual and environmental factors to physical activity level among Spanish adults. PLoS One. 2012; 7(6): e38693.

PubMed Abstract | Publisher Full Text | Free Full Text

151. Pollock K, Dahlenburg H, Nelson H, et al.: Human Mesenchymal Stem Cells Genetically Engineered to Overexpress Brain-derived Neurotrophic Factor Improve Outcomes in Huntington's Disease Mouse Models. Mol Ther. 2016; 24(5): 965-77.

PubMed Abstract | Publisher Full Text | Free Full Text

152. Gray M: Astrocytes in Huntington's Disease. Adv Exp Med Biol. 2019; 1175: 355-81.

PubMed Abstract | Publisher Full Text | Faculty Opinions Recommendation

153. Nicniocaill B, Haraldsson B, Hansson O, et al:: Altered striatal amino acid neurotransmitter release monitored using microdialysis in R6/1 Huntington transgenic mice. Eur J Neurosci. 2001; 13(1): 206-10. PubMed Abstract | Publisher Full Text

154. - Gu X, Greiner ER, Mishra R, et al.: Serines 13 and 16 are critical determinants of full-length human mutant huntingtin induced disease pathogenesis in HD mice. Neuron. 2009; 64(6): 828-40. PubMed Abstract | Publisher Full Text | Free Full Text | Faculty Opinions Recommendation

155. Kratter $\mathrm{IH}$, Zahed $\mathrm{H}$, Lau A, et al.: Serine $\mathbf{4 2 1}$ regulates mutant huntingtin toxicity and clearance in mice. J Clin Invest. 2016; 126(9): 3585-97. PubMed Abstract | Publisher Full Text | Free Full Text

156. Zala D, Colin $\mathrm{E}$, Rangone $\mathrm{H}$, et al:: Phosphorylation of mutant huntingtin at $\mathbf{S} 421$ restores anterograde and retrograde transport in neurons. Hum Mol Genet 2008; 17(24): 3837-46.

PubMed Abstract | Publisher Full Text

157. Wheeler VC, Auerbach W, White JK, et al:: Length-dependent gametic CAG repeat instability in the Huntington's disease knock-in mouse. Hum Mol Genet. 1999; 8(1): 115-22.

PubMed Abstract | Publisher Full Text

158. Wheeler VC, White JK, Gutekunst CA, et al.: Long glutamine tracts cause nuclear localization of a novel form of huntingtin in medium spiny striatal neurons in HdhQ92 and HdhQ111 knock-in mice. Hum Mol Genet. 2000; 9(4): 503-13.

PubMed Abstract | Publisher Full Text

159. Menalled LB, Sison JD, Wu Y, et al:: Early Motor Dysfunction and Striosomal Distribution of Huntingtin Microaggregates in Huntington's Disease Knock-In Mice. J Neurosci. 2002; 22(18): 8266-76. PubMed Abstract | Publisher Full Text | Free Full Text

160. Kuhn A, Goldstein DR, Hodges A, et al.: Mutant huntingtin's effects on striatal gene expression in mice recapitulate changes observed in human Huntington's disease brain and do not differ with mutant huntingtin length or wild-type huntingtin dosage. Hum Mol Genet. 2007; 16(15): 1845-61. PubMed Abstract | Publisher Full Text

161. Arnoux I, Willam M, Griesche N, et al.: Metformin reverses early cortical network dysfunction and behavior changes in Huntington's disease. elife. 2018; 7: e38744.

PubMed Abstract | Publisher Full Text | Free Full Text |

Faculty Opinions Recommendation 
162. Labuschagne I, Cassidy AM, Scahill RI, et al.: Visuospatial Processing Deficits Linked to Posterior Brain Regions in Premanifest and Early Stage Huntington's Disease. J Int Neuropsychol Soc. 2016; 22(6): 595-608. PubMed Abstract | Publisher Full Text

163. Neueder A, Landles C, Ghosh R, et al.: The pathogenic exon 1 HTT protein is produced by incomplete splicing in Huntington's disease patients. Sci Rep. 2017; 7(1): 1307.

PubMed Abstract | Publisher Full Text | Free Full Text

164. Sathasivam K, Neueder A, Gipson TA, et al.: Aberrant splicing of $\boldsymbol{H T T}$ generates the pathogenic exon 1 protein in Huntington disease. Proc Natl Acad Sci U S A. 2013; 110(6): 2366-70.

PubMed Abstract | Publisher Full Text | Free Full Text

165. Donzis EJ, Estrada-Sánchez AM, Indersmitten T, et al.: Cortical Network Dynamics Is Altered in Mouse Models of Huntington's Disease. Cereb Cortex. 2020; 30(4): 2372-88.

PubMed Abstract | Publisher Full Text | Free Full Text | Faculty Opinions Recommendation

166. Cepeda C, Galvan L, Holley SM, et al:: Multiple sources of striatal inhibition are differentially affected in Huntington's disease mouse models. J Neurosci. 2013; 33(17): 7393-406.

PubMed Abstract | Publisher Full Text | Free Full Text

167. Oldenburg IA, Sabatini BL: Antagonistic but Not Symmetric Regulation of Primary Motor Cortex by Basal Ganglia Direct and Indirect Pathways. Neuron 2015; 86(5): 1174-81.

PubMed Abstract | Publisher Full Text | Free Full Text

168. Langfelder $\mathrm{P}$, Cantle JP, Chatzopoulou D, et al.: Integrated genomics and proteomics define huntingtin CAG length-dependent networks in mice. Nat Neurosci. 2016; 19(4): 623-33.

PubMed Abstract | Publisher Full Text | Free Full Text
169. Alexandrov V, Brunner D, Menalled LB, et al.: Large-scale phenome analysis defines a behavioral signature for Huntington's disease genotype in mice. Nat Biotechnol. 2016; 34(8): 838-44.

PubMed Abstract | Publisher Full Text

170. Ament SA, Pearl JR, Grindeland A, et al:: High resolution time-course mapping of early transcriptomic, molecular and cellular phenotypes in Huntington's disease CAG knock-in mice across multiple genetic backgrounds. Hum Mol Genet. 2017; 26(5): 913-22.

PubMed Abstract | Publisher Full Text | Free Full Text

171. Alcalá-Vida R, Seguin J, Lotz C, et al.: Age-related and disease locus-specific mechanisms contribute to early remodelling of chromatin structure in Huntington's disease mice. Nat Commun. 2021; 12(1): 364. PubMed Abstract | Publisher Full Text | Free Full Text | Faculty Opinions Recommendation

172. Morozko EL, Smith-Geater C, Monteys AM, et al:: PIAS1 modulates striatal transcription, DNA damage repair, and SUMOylation with relevance to Huntington's disease. Proc Natl Acad Sci U S A. 2021; 118(4): e2021836118. PubMed Abstract | Publisher Full Text | Free Full Text | Faculty Opinions Recommendation

173. Maiuri T, Hung CLK, Suart C, et al.: DNA Repair in Huntington's Disease and Spinocerebellar Ataxias: Somatic Instability and Alternative Hypotheses. J Huntingtons Dis. 2021; 10(1): 165-73. PubMed Abstract | Publisher Full Text | Free Full Text | PubMed Abstract | Publisher Full Text
Faculty Opinions Recommendation

174. Pouladi MA, Xie Y, Skotte NH, et al.: Full-length huntingtin levels modulate body weight by influencing insulin-like growth factor 1 expression. Hum Mol Genet. 2010; 19(8): 1528-38.

PubMed Abstract | Publisher Full Text | Free Full Text 